\title{
¿Es posible soñar en niveles avanzados? Cuentos tradicionales en el aula de ELE/EL2
}

Recibido: marzo 2011

\author{
Ana María AguILAR LÓPEZ \\ Universidad de Burgos \\ Departamento de Didácticas Específicas. \\ Área de Didáctica de la Lengua y la Literatura \\ amaguilar@ubu.es
}

Aceptado: marzo 2012

\section{RESUMEN}

En el siguiente documento tratamos de legitimar la presencia de los cuentos tradicionales en el aula de Español Lengua Extranjera (ELE) y Español Segunda Lengua (EL2). Tras una sucinta introducción teórica en la que se hace apología de los cuentos como recurso, presentamos una serie de actividades realizadas con diferentes cursos de estudiantes matriculados niveles avanzados de Cursos de Español de la Universidad de Burgos.

Palabras clave: Español Lengua Extranjera (ELE), Español Segunda Lengua (EL2), cuentos, nivel avanzado. B2. C1.

Est-il possible de rêver dans des niveaux avancés ? Contes traditionnels dans la classe d'ELE/EL2.

\section{RÉSUMÉ}

Dans l'article suivant, nous essayons de légitimer la présence des contes traditionnels dans la classe d'Espagnol Langue Étrangère (ELE) et Espagnol Deuxième Langue (E12). Après une succincte introduction théorique où l'on fait apologie des contes comme recours, nous présentons une série d'activités réalisées avec des différents cours d'étudiants immatriculés dans les niveaux avancés de Cours d'Espagnol de l'Université de Burgos.

Mots-clé: Espagnol Langue Étrangère (ELE), Espagnol Deuxième Langue (EL2), contes, niveau avancé. B2.C1.

Is it possible to dream in advanced levels? Traditional stories in the SFL and SSL classroom.

\section{ABSTRACT}

In the following article, we will try to legitimize the presence of the traditional stories in the Spanish as Foreign Language (SFL) and Spanish as second language (SSL) classrooms. After a theoretical introduction on the apology of the stories we will show a series of activities as a resource for different advanced groups in Courses in Spanish language and culture at the University of Burgos.

Key words: Spanish as a foreign language (SFL), Spanish as a second language (SSL), stories, advanced level. B2. C1. 
SUMARIO 0. Introducción. 1. El porqué de los cuentos tradicionales en la clase de ELE/EL2. 2. Experiencias de aula. 2.1 Actividades con el nivel B2.2- C1. 2.1.1 Entramos en el mundo de los cuentos tradicionales.2.1.2 Trabajamos con Ratón Pérez. 2.1.3 Finalizamos con una canción sobre cuentos. 2.2 Actividades con el nivel B2. 2.2.1 Trabajamos con Caperucita Roja. 3. Conclusión.

\section{INTRODUCCIÓN}

Dado que los cuentos forman parte del ingente material literario, su presencia en la clase de una lengua extranjera o segunda lengua quedará justificada, en la medida en la que lo esté la presencia de la literatura. En este sentido no pocos autores han tratado de legitimar y de defender las ventajas derivadas de su inclusión en el aula. En el artículo titulado "El texto literario en la clase de ELE: propuestas y modelos de uso", Khemais Jouini (2008) recapitula y analiza algunos de los argumentos tradicionalmente esgrimidos para respaldar el uso de la literatura en el aula de español lengua extranjera. No pretendemos aquí reproducir dicho artículo, pero sí citar someramente algunos de esos argumentos puesto que, como decimos, nos permiten al mismo tiempo legitimar la presencia de los cuentos tradicionales en la clase de ELE/EL2.

Entre los citados argumentos están por ejemplo el hecho de que la literatura proporciona una muestra de lengua real cuyo objetivo de creación es en la mayoría de los casos hedonista, es decir, persigue el disfrute del acto lector. De forma que el texto literario es un elemento motivador en sí mismo por cuanto ofrece la posibilidad de evocar otros espacios, tiempos y personajes, y vivir historias apasionantes en las cuales los discentes proyectan sus expectativas, sus experiencias, sus sentimientos, etc. llegándose a identificar muchas veces con actitudes de los personajes y percepciones de los autores, pues, no en vano, los textos literarios se tejen con temas universales e inherentes a la propia existencia de la especie humana.

Es precisamente por esa motivación que suscita la idea de disfrutar con la lectura de textos literarios, que el alumnado percibe en la literatura un recurso adecuado no sólo para el aula, sino también fuera de ésta, de ahí que muchos aprendices de lenguas tomen los textos literarios como instrumento para permanecer en contacto con la lengua meta más allá de la instrucción formal que proporcionan los cursos de idiomas.

$\mathrm{Y}$ es que la literatura no deja de ser aducto, o muestra de lengua, que permite a los alumnos practicar la lengua objeto y percibir las formas lingüísticas en un contexto, lo cual favorece su asimilación, ya sea de forma consciente o inconsciente, puesto que la obnubilación por el propio devenir de los hechos que se están leyendo provoca que en numerosas ocasiones el discente persiga el significado y no siempre repare en la forma en la que éste es transmitido.

Además la literatura se presta para trabajar todas las actividades de lengua. Que nadie se llame a error y colija que, dado que es un recurso especialmente escrito, ha de destinarse en exclusiva para el desarrollo de la comprensión escrita. Quedarnos con esta visión reduccionista equivaldría a falsear la realidad. 
No sólo es posible emplear la literatura para el desarrollo de la competencia comunicativa, sino también cultural, en tanto en cuanto los textos literarios reflejan las sociedades en las que surgen y los valores que en ellas imperan. A este respecto, María Dolores Albaladejo (2007, 7), haciéndose eco de las palabras de Collie y Slater, explica que:

(...) aunque el mundo de una novela, obra de teatro o historia corta sea un mundo creado, ofrecen un vívido contexto en el que personajes de diversos extractos sociales pueden ser representados. De esta forma el lector puede descubrir sus pensamientos, sentimientos, costumbres y hasta posesiones, lo que compran, en qué creen, qué temen, con qué disfrutan, cómo hablan y se comportan a puerta cerrada, en resumen, pueden dar rápidamente al lector extranjero una apreciación de los códigos y preocupaciones que estructuran una sociedad real, y en concreto de la sociedad del país donde se habla la lengua que están aprendiendo.

Por su parte, Asunción Barreras Gómez $(2007,315)$ resalta que "La literatura, en general, permite a los alumnos comprender y apreciar otras culturas e ideologías diferentes a las suyas. Por tanto, aprenden a respetar esas otras culturas y a involucrarse en ellas".

\section{EL PORQUÉ DE LOS CUENTOS TRADICIONALES EN LA CLASE DE ELE/EL2}

En este apartado nos proponemos abordar, para refutarlas, ciertas objeciones o reticencias que los docentes hayan podido percibir al plantearse el empleo de los cuentos tradicionales como recurso en la clase de ELE/EL2.

Así, es posible que haya quien considere que los cuentos tradicionales no tienen cabida en la sociedad actual, menos ingenua y más sofisticada que la de antaño, en la que surgieron. Pero lo cierto es que gozan de plena vigencia, ya que se prestan a nuevas interpretaciones desde cualquier espacio y tiempo. Prueba de ello son las constantes adaptaciones al cine, versiones impresas de los clásicos, etc. que cada año aparecen.

Habrá quien objete que su estilo, un tanto arcaico, con giros y convenciones de otro tiempo, no los convierten en la mejor muestra de lengua que podamos ofrecer a los alumnos extranjeros cuya lengua materna no es el español. Sin embargo unido a este estilo arcaico, no es extraño encontrar un lenguaje cuidado, elaborado, sencillo y correcto. Características que los convierten en un material real, muy útil para mostrar las convenciones del lenguaje escrito. Además, como cualquier otro texto literario, ayudan a consolidar y desarrollar la lengua, ya que ofrecen un contexto que hace que la nueva información sea más significativa y por ende recordable. Por otro lado, su extensión, por lo general menor que la de otros textos literarios como la novela el ensayo o el teatro, facilita que a partir de ellos se profundice en ciertos aspectos de diversa índole que el docente o los alumnos consideren relevantes y que su lectura se plantee como un reto más asequible, al menos para los alumnos de niveles más bajos.

Aún con todo y con eso, se podrían tener ciertas reservas en cuanto a las posibilidades de uso que éstos ofrecen en el aula, pues tras la lectura de varios 
cuentos tradicionales, es muy probable que se incurra en la monotonía y que ésta termine generando el desinterés de los discentes, con lo cual no tendría sentido proponer un trabajo con ellos más allá de alguna lectura puntual. Esto podría ser así, en efecto, si limitásemos dicho trabajo a la lectura de cuentos de antemano conocidos, pero el mundo de los cuentos no se agota tan rápidamente, ya que podemos trascender la frontera del relato en sí y diseñar actividades centrándonos en un sinfín de posibilidades: los personajes, los títulos, las biografías de autores, las ilustraciones, las versiones, noticias aparecidas sobre ellos, exposiciones que traten sobre los cuentos, etc. Es decir, a partir del tema de los cuentos se abre la posibilidad de trabajar en clase otras tipologías textuales e infinidad de funciones lingüísticas.

No es descabellado tampoco que los cuentos nos parezcan un recurso adecuado para una clase de ELE/ EL2, pero rehusemos trabajar con los cuentos tradicionales, amparándonos en la idea de que conocer el argumento de antemano puede desmotivar al alumnado. Aunque lo cierto es que esta misma característica, es decir, el conocimiento de la materia a tratar, no ha de implicar sistemáticamente su exclusión del aula, antes bien, nos ofrece la posibilidad de aprovecharla para plantear una docencia diferente. Por otro lado, el hecho de que el alumnado conozca el argumento de un cuento, favorece que éste adopte una postura confiada y de cierta seguridad respecto a lo que se le va a proponer. Además, en casos en los que los alumnos no se conocen mucho y, especialmente si proceden de diferentes países, introducimos a través de los cuentos la posibilidad de partir de un punto que es común a todo el grupo y que les resulta familiar a nivel individual.

No podemos obviar el hecho de que, si bien es cierto que existen muchos cuentos tradicionales que son considerados como tales en muchos países y por tanto es muy probable que, si no todos, la mayoría de nuestros discentes los conozcan; también es cierto que existen otros muchos cuentos tradicionales propios de cada país, que seguramente hayan tenido menos difusión y sean menos conocidos por el alumnado extranjero que estudia la lengua en la que se crearon, tal es el caso de Ratón Pérez. Por tanto, los cuentos tradicionales, además pueden reflejar modos de pensar y de actuar, costumbres, interpretaciones de la realidad o valores propios de la cultura en la que surgen. Al incluirlos en el aula abrimos la puerta a la confrontación o cotejo de la cultura de la lengua meta y la propia del aprendiz. En la medida que acerquemos la cultura de la lengua meta al alumnado la entenderá y en la medida que la entienda se sentirá más próximo a ella, por lo que la distancia social percibida por el alumno será menor y se incrementarán las opciones de aculturación ${ }^{1}$.

${ }^{1}$ Según la teoría de John Schumann (Liceras 1992, 123-141) la distancia social y la psicológica pueden ser las causas de que las interlenguas de los aprendices no evolucionen y se mantengan en un estado semejante al de las lenguas pidgin. La distancia social estaría formada a su vez por varios factores entre ellos 1. la actitud del grupo social al que pertenece el aprendiz hacia el grupo social que tiene como lengua materna la lengua objeto y 2. la asimilación, aculturación o preservación de la cultura de origen por parte del grupo 
No es por casualidad que el Plan Curricular del Instituto Cervantes contempla entre los Referentes Culturales (vol. B, 2006, 537) el contenido del cuento en España e Hispanoamérica así como otros géneros, incluida, dentro de éstos, la literatura para niños.

Llegados a este punto puede ser que nos parezcan útiles como recurso didáctico en un aula de ELE/EL2 infantil, pero que tengamos nuestras reservas al pensar en un aula de discentes adultos. Pese a que solemos asociar el público infantil a los cuentos tradicionales, este hecho no les resta valor desde un punto de vista didáctico. Si los cuentos utilizados son muy conocidos, brindaremos al alumno adulto la posibilidad de rememorar su infancia través de los cuentos, activar recuerdos, en muchos casos positivos, en un contexto destinado al aprendizaje de la L2/LE, lo que favorece que el alumno se posicione ante el aprendizaje con motivación.

Los cuentos son un material atractivo en sí mismo, no sólo por esa posible conexión con la infancia de nuestros alumnos adultos, sino también porque a través de su presencia en el aula se genera la posibilidad de dar cabida al mundo de la fantasía, de la creatividad sin límites. El aula de ELE/EL2 se convierte entonces en un espacio en el que está permitido traspasar la frontera de lo real, dar rienda suelta a la imaginación y que aparezca lo irreal, lo maravilloso ${ }^{2}$. Al incluirlos en el aula podemos analizar las conductas de los personajes y mediante esos análisis dejar que el alumno exprese su "уо".

En palabras de María Teresa Crespo Sastre y Carlos González Villán (2007, 174): "El cuento es una medicina que libera tensiones, que elimina cargas acumuladas, trabajos, problemas. Se utiliza mucho en consultas psicológicas y psiquiátricas para autoexplorarse y hacer reflexión crítica".

Cabe la posibilidad de que los cuentos nos parezcan más adecuados para niveles más bajos, ya que en niveles altos, los alumnos dominan más la lengua meta y la narración puede resultar demasiado simple no permitiendo al docente desarrollar

social al que pertenece el aprendiz. Se produce asimilación del grupo de adquisición de segunda lengua cuando abandona su modo de vida y sus valores y adopta los del grupo de la lengua meta. Aculturación cuando adopta valores del grupo de la lengua meta pero mantiene su estilo de vida y sus modelos culturales. Preservación: si rechaza el estilo de vida y valores del grupo de la lengua objeto manteniendo en lo posible su propia cultura.

Teniendo en cuenta estos y otros factores que componen la distancia social, Schumann concluyó que a mayor distancia social, más dificultades para abordar el aprendizaje de la L2. La distancia social será menor si ambos grupos (aquél del cual procede el aprendiz y el propio de la lengua meta) están dispuestos a la aculturación y si ambos grupos generan actitudes positivas entre ellos.

${ }^{2}$ Según Joanne Collie y Stephen Slater (1991, 5): “At a productive level, students of literature will, we hope, become more creative and adventurous as they begin to appreciate the richness and variety of the language they are trying to master and begin to use some of that potential themselves". 
todo el potencial de los discentes. Aunque tampoco esto es así, ya que a partir de un mismo cuento podemos trabajar diferentes funciones comunicativas, áreas léxicas, estructuras, etc. Téngase en cuenta también que los cuentos tradicionales poseen un argumento versátil $\mathrm{y}$, aunque incluyen personajes tipo, no son ni predecibles ni personajes planos, es decir, tienen cierto grado de complejidad estructural.

Por todo lo dicho anteriormente, consideramos que los cuentos, como material didáctico pueden resultar tan rentables y lúdicos como lo puedan ser otras tipologías textuales, todo dependerá del enfoque que se dé al trabajo que queremos llevar al aula.

En definitiva, la presencia de los cuentos en el aula de ELE/EL2 para adultos puede justificarse desde varios puntos de vista: como elemento cultural que refleja los valores de una comunidad, como punto de encuentro entre los diferentes alumnos, como muestra real o adaptada de la lengua objeto, como recurso a través del cual desarrollar las actividades comunicativas de la lengua (comprensión y expresión orales, comprensión y expresión escritas, mediación e interacción), etc.

\section{EXPERIENCIAS DE AULA}

A continuación exponemos una serie de actividades relacionadas con los cuentos tradicionales que se han llevado a cabo con alumnos de niveles avanzados de Cursos de Español de la Universidad de Burgos.

El primer bloque de actividades (2.1) se implementó con 10 alumnos de nivel C1, procedentes de la Western Michigan University de Estados Unidos, es decir, todos los alumnos compartían la misma lengua materna: el inglés. Sin embargo, dos de los discentes eran hijos de inmigrantes hispanohablantes y utilizaban el español para relacionarse con la familia, por lo que podrían ser catalogados como bilingües. Los alumnos se alojaron con familias españolas y el curso se impartió en la Universidad de Burgos, esto es, la experiencia se desarrolló en un contexto de inmersión lingüística (Español Segunda Lengua). Fue un curso intensivo de lengua española con una duración total de 84 horas que se impartieron entre los meses de agosto y septiembre.

Por su parte, el segundo bloque de actividades (2.2) se realizó en un aula con 15 estudiantes Erasmus de nivel B2, procedentes de diferentes universidades y países europeos, lo que implica que no todos los alumnos tenían la misma lengua materna. Las lenguas maternas de los discentes eran: alemán, inglés, italiano, checo y francés. Los estudiantes Erasmus estaban en un contexto de inmersión lingüística (Español Segunda Lengua), aunque no todos compartían piso con españoles, el curso se desarrolló también en la Universidad de Burgos. Sin embargo no se trataba de un curso intensivo de lengua española. La duración total del curso de español fue de 40 horas impartidas entre los meses de marzo y mayo.

\subsection{Actividades con el nivel C1}

\subsubsection{Entramos en el mundo de los cuentos tradicionales}

Actividad comunicativa de la lengua: Expresión oral. Comprensión escrita. 
Descripción de la actividad: Escribimos en la pizarra algunas frases y vocabulario relacionados con los cuentos: Tener mucho cuento. Vivir del cuento. Venir a cuento de algo. No me vengas con cuentos. Mucho cuento le echas tú. Eso son cuentos chinos. Y lo demás, son cuentos. Aplícate el cuento. Eso es del año de Mari Castaña. Esto es el cuento de nunca acabar. En parejas los alumnos han de pensar un posible significado para cada expresión, después corregimos en gran grupo la actividad y aclaramos las expresiones con ejemplos.

A continuación les presentamos la expresión Tener más cuento que Calleja y les pedimos que conjeturen sobre su posible significado. Les invitamos a leer el texto que sigue sobre Saturnino Calleja Fernández.

\section{SATURNINO CALLEJA FERNÁNDEZ ${ }^{3}$}

Nació en Burgos (España), a mediados del siglo XIX. Su padre, Fernando Calleja Santos, fundó en 1876 un negocio de librería y encuadernación, en la calle de la Paz, en Madrid, que Saturnino compró posteriormente y lo convirtió en la Editorial Calleja. Esta editorial llegó a ser la más popular en España, en Hispanoamérica y en Filipinas.

Saturnino Calleja realizó importantes contribuciones al mundo editorial de la época. Por un lado sacó al mercado tiradas de cuentos con una edición más barata, pero siempre bien presentada y de calidad. Estos cuentos eran asequibles gracias al escaso margen de beneficio que obtenía de ellos. Aunque también la editorial contaba con colecciones de cuentos más lujosas como Perla.

El abaratamiento de los cuentos hizo que fueran accesibles a todas las clases sociales, ya que estaban al alcance de los bolsillos de menor poder adquisitivo, ello supuso la difusión de los cuentos, el fomento de la lectura entre los niños de las primeras décadas del siglo XX y el aumento de las ventas. De hecho la expresión " $i$ Tienes más cuento que Calleja!" deriva de las numerosas tiradas y la variedad de cuentos que la editorial publicó.

Su segunda contribución es que ilustró profusamente todos estos cuentos con dibujos de los mejores ilustradores de la época, logrando así unos cuentos más atractivos a los ojos infantiles.

Además, gracias a Calleja, los niños españoles conocieron los cuentos de Hans Christian Andersen o los de los hermanos Grimm, Los viajes de Gulliver, Las mil y una noches y toda una serie de versiones de autores españoles. Estos cuentos eran modificados para no aburrir o asustar a los niños lectores. Entre las "licencias" que los Calleja se permitieron, estaban las de cambiar los argumentos, los finales, los nombres de los personajes (así 'Hansel y Gretel' fueron 'Juanito y Margarita' y 'El Barón Munchausen' pasó a ser el

\footnotetext{
${ }^{3}$ Texto adaptado de http://burgospedia1.wordpress.com/2010/10/26/saturnino-calleja-editorfundador-de-la-editorial-calleja/ y http://es.wikipedia.org/wiki/Saturnino_Calleja
} 
Barón de la Castaña) o algunos detalles (El soldadito de plomo que tantos avatares sufrió en su aventura, lo hizo por devoción a la Virgen del Pilar y no por el amor de la muñeca bailarina, según la primera edición de este cuento infantil que la Editorial Calleja publicó en España). En ocasiones estas modificaciones respondían al deseo de instruir y dar ejemplo moral y ético a los niños.

Los cuentos de Calleja también recogían tradiciones anónimas así como otros textos inéditos, la mayoría de ellos elaborada por escritores anónimos asalariados importantes. Calleja contó, entre otros, con la colaboración de Salvador Bartolozzi y de otros artistas algunos ligados a la famosa revista del momento "Blanco y Negro", como Narciso Méndez Bringa o Santiago Regidor. Conforme fue avanzando el siglo XX, fueron uniéndose otros autores más jóvenes, representantes de las nuevas corrientes estéticas. Se desconoce la relación exacta de los escritores, porque los archivos de la editorial desaparecieron en la Guerra Civil, pero sí se sabe que entre los trabajadores de la editorial estuvo un jovencísimo Juan Ramón Jiménez.

Algunos de los cuentos fueron compuestos incluso por el propio Saturnino Calleja, de hecho el final de innumerables cuentos de habla hispana es de invención suya, como “...y fueron felices y comieron perdices, y a mí no me dieron porque no quisieron.

Seguidamente valoramos la comprensión del texto a partir de unas preguntas.

Al plantearnos la posibilidad de hacer preguntas tras la lectura de un texto, a través de las cuales podamos valorar si el alumnado ha comprendido el texto propuesto, tenemos presente los comentarios realizados al respecto por Penny Ur (1997, 143-146) y la clasificación propuesta por Isabel Solé (2005, 138-142), quien, a su vez se basa en Pearson y Johnson (1978) y Raphael (1982). Dicha propuesta consiste en diferenciar tres tipos de preguntas: 1 preguntas de respuesta literal, 2 preguntas piensa y busca y 3 preguntas de elaboración personal.

Las preguntas de respuesta literal son aquéllas cuya formulación reproduce parte del texto por el que se pregunta, con lo cual ofrecen una pista infalible para localizar la respuesta, de ahí que no sean fiables a la hora de evaluar la comprensión que nuestros alumnos han tenido del texto propuesto, ya que, como Penny Ur $(1997,143)$ demuestra, es posible contestarlas sin que se haya comprendido el texto. El segundo grupo de preguntas, las de piensa y busca, exigen una respuesta que es fruto de inferencias o deducciones que hace el lector a partir del texto, es decir, requieren que el lector relacione la información del texto e interprete su contenido. Por último, las preguntas de elaboración personal toman como referente el texto, pero su respuesta no se puede deducir a partir de la información que éste ofrece, ya que implican que el lector apele a su bagaje cognitivo y exprese opiniones u otros conocimientos relacionados con el tema propuesto.

Además, tal y como aconseja Isabel Solé (2005, 137), pretendemos que las preguntas hechas al hilo de éste y otros textos trabajados en este artículo, sean pertinentes, lo cual implica que ayuden al lector a identificar el tema y las deas principales del texto y que sean coherentes con los objetivos de lectura planteados. 
Las preguntas que hacemos en esta ocasión son las siguientes:

- ¿Cuál crees que es el significado de la expresión Tener más cuento que Calleja?

- ¿Cuáles fueron las aportaciones fundamentales de Saturnino Calleja?

- ¿En qué tres grupos se pueden clasificar sus cuentos?

- ¿Qué elementos modificaba Calleja de los cuentos extranjeros?

- Además de la famosa fórmula "y fueron felices y comieron perdices", que según el texto se debe a Calleja, ¿qué otras fórmulas conoces para finalizar un cuento en español?

- ¿Y para comenzarlo?

Las anteriores preguntas se pueden contestar con la información del texto, a excepción de las dos últimas, que dan opción a que el alumnado aporte o explicite conocimientos previos sobre fórmulas fijas usadas para comenzar y finalizar cuentos. Una vez que los alumnos han tenido su turno para expresar sus conocimientos, la profesora comprueba que los alumnos hayan mencionado fórmulas finales como: ...y colorín colorado este cuento se ha acabado o ... y colorín colorete por la chimenea salió un cohete, etc. o comienzos como: Érase una vez..., Habia una vez..., Esto es que se era..., En un país muy lejano..., etc. En caso de que los alumnos los desconozcan, es la profesora quien los presenta.

Evaluación: La evaluación de esta actividad atiende a los siguientes ítems:

- E1/la discente ha comprendido el significado literal y metafórico de la expresión Tener más cuento que Calleja.

- E1/la discente conoce formas de encabezar y finalizar un cuento.

- El/la discente ha comprendido el texto.

- El/la discente conoce expresiones relacionadas con el mundo de los cuentos.

\subsubsection{Trabajamos con Ratón Pérez}

Actividad comunicativa de la lengua: Expresión oral. Comprensión escrita.

Descripción de la actividad: Para trabajar con este cuento utilizamos información disponible en la red, por ello, si algún docente quisiera aplicar estas actividades, sería necesario que tuviera acceso a Internet en el espacio donde imparte su curso, o bien que avisara a sus alumnos para que llevaran su ordenador portátil o que llevara a los discentes al aula de ordenadores, si es que da clases en un centro que dispone de ella. En nuestro caso, contamos con la suerte de tener un aula con acceso a Internet y un cañón para proyectar la imagen y hacerla visible para todos los alumnos. 
Avisamos a los estudiantes de que vamos a trabajar con un personaje de cuentos que ha sido dibujado en numerosas ocasiones. La profesora proyecta en clase algunas de las ilustraciones que aparecen en el enlace del Instituto Cervantes sobre el Ratón Pérez http://cvc.cervantes.es/actcult/raton/default.htm disponibles en la sección de Exposición ${ }^{4}$. La última ilustración que proyectamos es la número 56, que incluye esta adivinanza: Nunca me has visto/Crees que no existo/ Me cuelo por todos los lados/ Te cambio tu diente malo/ Por un regalo/ Soy un ratón muy salao.

Tras esta presentación les damos el nombre del personaje y planteamos algunas cuestiones a los discentes para ser contestadas en gran grupo de forma oral. En concreto las preguntas que hacemos son las siguientes: ¿quién creéis que es? ¿Qué es lo que hace? ¿Por qué o para qué creéis que existe una historia así? ¿Hay en vuestra cultura un personaje similar? Contad su historia.

A continuación les indicamos la existencia del anterior enlace del Instituto Cervantes sobre este personaje. Indagando en este $\mathrm{u}$ otros enlaces similares, los alumnos en parejas, y a modo de gymkhana, han de contestar al siguiente cuestionario:

\section{RATÓN PÉREZ (Cuestionario)}

- ¿Quién es el Padre Luis Coloma?

- ¿Por qué decidió hacerse religioso (jesuita)?

- ¿A qué importante academia perteneció?

- La primera publicación del texto de Ratón Pérez aparece en 1902 junto a otras narraciones. Pero ¿cuándo se publica por primera vez de forma independiente?

- ¿Dónde se guarda un ejemplar de esta primera edición?

- ¿Dónde se conserva el cuento de Ratón Pérez manuscrito y con dedicatoria del autor al rey Alfonso XIII?

- ¿Por qué es significativo que en el cuento de Ratón Pérez aparezca un personaje que se llama Buby?

- ¿Para quién se escribió este cuento originariamente? ${ }^{5}$

${ }^{4}$ En su defecto podemos introducir el término: Ratón Pérez en cualquier buscador y descargar algunas imágenes. Para finalizar con la adivinanza que aparece en la ilustración 56 del enlace del Instituto Cervantes. Lo mismo sucede con los enlaces que se mencionan más adelante, en realidad pretendemos dar cabida a Internet en el aula y que el alumno se acostumbre a leer en la red textos en español. Por otro lado la información que proporcionan los enlaces es, en muchos casos, compartida, por lo que se puede acudir a los que sugerimos nosotros o a otros.

${ }^{5}$ El Padre Luis Coloma es el autor de Ratón Pérez. Decidió hacerse jesuita a partir de un accidente que tuvo, cuya gravedad fue tal que estuvo muy cerca de la muerte. Perteneció a la Real Academia de la Lengua Española. El texto se publica por primera vez de forma independiente en 1911. Un ejemplar del cuento se guarda en la biblioteca del Palacio Real. 
Evaluación: La evaluación de esta primera parte de la actividad responde a los siguientes ítems:

- El/la discente ha empleado correctamente fuentes en español disponibles en Internet para tratar de responder a las preguntas planteadas.

- El/la discente ha localizado y comprendido los textos en los que se da la información que requiere la actividad.

- El/la discente conoce el personaje tradicional de Ratón Pérez, qué es lo que hace y otras curiosidades.

Actividad comunicativa de la lengua: Comprensión escrita.

Descripción de la actividad: Tras corregir las preguntas anteriores repartimos a los alumnos los fragmentos de Ratón Pérez que aparecen más abajo, pero sin que haya ninguna palabra subrayada. Durante la lectura los alumnos han de elegir la información que consideran correcta entre las tres disponibles dentro de cada paréntesis, es decir, la que nosotros ofrecemos aquí subrayada.

\section{RATÓN PÉREZ ${ }^{6}$ (fragmentos del Padre Luis Coloma)}

(...) comiendo un día el Rey unas sopitas, se le comenzó a menear un diente. Alarmóse la corte entera, y llegaron, uno en pos de otro, los médicos de Cámara. (...) Todo indicaba que había llegado para Su Majestad la hora de (ir al dentista - mudar los dientes - su revisión médica).

Reunióse en consulta toda la Facultad; telegrafióse a Charcot, por si venía complicación nerviosa, y decretóse al cabo (sacar a Su Majestad el diente - esperar a que se cayera el diente por sí solo - ingresarle en un hospital). Los médicos quisieron cloroformizarle, y el Presidente del consejo sostuvo porfiadamente esta opinión, por ser él tan impresionable, que nunca dejaba de hacerlo cada vez que se cortaba el pelo. Pero el rey Buby era animoso y valiente y empeñóse en arrostrar el peligro (otro día que tuviera más valor - cara a cara - con ayuda de anestesia) (...).

Buby era el apodo cariñoso con el que la reina llamaba a su hijo Alfonso XIII. Cuando Alfonso XIII tenía 8 años se le cayó un diente y desde palacio le pidieron a Luis Coloma que escribiera un cuento sobre este tema, el resultado es Ratón Pérez.

6 Tanto éste como el siguiente cuadro incluye fragmentos extraídos de COLOMA, Luis (2002): Ratón Pérez, Madrid, Asociación Española de Amigos del libro infantil y juvenil. 
Atáronle, pues, al suyo una hebra de seda encarnada, y el médico más anciano comenzó a tirar con tanto pulso y acierto que a la mitad del empuje hizo el Rey un pucherito, y saltó el diente tan blanco, tan limpio y tan precioso como una perlita sin engaste.

Recogiólo en un azafate de oro el gentil hombre Grande de guardia, y fue a presentarlo a Su Majestad la Reina. (...) esta Señora, que como mujer (lista - moderna - dócil) no fiaba de aduladores y era muy prudente y amiga de la tradición, resolvió que el rey Buby escribiese a Ratón Pérez una atenta carta y pusiese aquella misma noche el diente debajo de su almohada, como ha sido y es uso común y constante de todos los niños, desde que el mundo es mundo, sin que haya memoria de que nunca dejase Ratón Pérez de venir a (robar - recoger - comprar) el diente y a dejar en cambio un espléndido regalo. (...)Apuradillo se vio el rey Buby para escribir la carta; pero consiguiólo al cabo (...).

Acostóse aquella noche más temprano que de costumbre, y mandó que dejasen encendidos en la alcoba todos los candelabros y arañas. Puso con mucho primor (en un vaso con agua, el diente - al lado de una ratonera, el diente - debajo de la almohada la carta con el diente dentro), y sentóse encima dispuesto (a esperar a Ratón Pérez - a dormir - irse a otra habitación del palacio) aunque fuese necesario velar hasta el alba.

Ratón Pérez tardaba y el Reyecito se entretuvo en pensar el discurso que había de pronunciarle. A poco abría Buby mucho los ojitos, (luchando contra el sueño que se los cerraba - para ver mejor - porque tenía algo de miopía): cerróselos al fin del todo, y el cuerpecillo resbaló buscando el calor de las mantas y la cabecita quedó sobre la almohada, escondida tras un brazo, como esconden los pajaritos la suya debajo del ala.

De pronto sintió una cosa suave que le rozaba la frente. Incorporóse de un brinco, sobresaltado, y vio delante de sí, de pie sobre la almohada, (una pluma enorme - un ratón

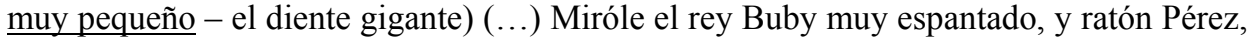
al verle despierto, quitóse el sombrero hasta los pies, inclinó la cabeza según el ceremonial de corte, y en esta actitud reverente esperó a que Su Majestad hablase.

Pero Su Majestad no dijo nada, porque el discurso se le olvidó de pronto, y después de pensarlo mucho, tan sólo acertó a decir algún tanto azorado: "Buenas noches" (...) Conocíase a la legua que era éste un ratón muy de mundo (...). Su conversación era variada e instructiva y su erudición pasmosa (...)

Era tarde, y como el rey Buby no pensaba en despedirle, Ratón Pérez insinuó hábilmente, sin faltar a la etiqueta, (que necesitaba dinero y quizá él podría dárselo, ya que era un rey - que a él no le dejaría un regalo puesto que él podría pagar cuantos quisiera - que le era preciso acudir aquella misma noche a la calle de Jacometrezo número 64 para recoger el diente de otro niño muy pobre, que se llamaba Gilito). (...)

Antojósele al rey Buby acompañarle en aquella expedición, y así se lo pidió a Ratón Pérez con el mayor ahínco. 
Una vez que los alumnos han intentado elegir las diez opciones correctas, por las que se les pregunta. Van a corregir sus respuestas con la siguiente tabla. En ella figuran las soluciones a cada uno de los diez ítems por los que se les ha preguntado durante la lectura, pero estas soluciones están reformuladas y desordenadas. Los alumnos, en parejas, han de relacionar cada frase de la tabla con uno de los fragmentos que aparecen en el texto superior. Para ver si las respuestas que habían elegido antes eran las correctas. Después han de ordenar el texto reformulado.

\begin{tabular}{|c|c|c|}
\hline Orden & Texto reformulado & $\begin{array}{c}\text { Correspondencia con el texto } \\
\text { original }\end{array}$ \\
\hline & $\begin{array}{l}\text { El rey Buby quiso afrontar el peligro sin } \\
\text { recurrir a ningún remedio, pese a que los } \\
\text { médicos quisieron ponerle cloroformo. }\end{array}$ & \\
\hline & $\begin{array}{l}\text { En resumidas cuentas, que al final el rey } \\
\text { Buby vio a Ratón Pérez. }\end{array}$ & \\
\hline & $\begin{array}{l}\text { Como venía siendo costumbre, el niño } \\
\text { dejó el diente y una carta debajo de la } \\
\text { almohada. Ahora bien, lo que pretendía } \\
\text { hacer después, conocer al ratón, era del } \\
\text { todo inusitado. }\end{array}$ & \\
\hline & $\begin{array}{l}\text { La reina era una mujer inteligente, por } \\
\text { consiguiente no escuchaba a quienes } \\
\text { trataban de hacerle la pelota. }\end{array}$ & \\
\hline & $\begin{array}{l}\text { El rey Buby intentaba no pestañear, asíy } \\
\text { todo, el sueño terminó por vencerlo. }\end{array}$ & \\
\hline & $\begin{array}{l}\text { El diente se movía, de ahi que todos } \\
\text { dedujeran que el rey Buby iba a empezar } \\
\text { a perder sus dientes de leche. }\end{array}$ & \\
\hline & $\begin{array}{l}\text { Debido a que era un ratón muy educado, } \\
\text { no dijo directamente que se tenía que ir. } \\
\text { Asi pues, se limitó a sugerir que tenía que } \\
\text { visitar otra calle para recoger el diente de } \\
\text { otro niño. }\end{array}$ & \\
\hline & $\begin{array}{l}\text { Ratón Pérez siempre ha cumplido con su } \\
\text { labor. Dicho de otro modo, no se conoce } \\
\text { ningún caso en el que haya dejado el } \\
\text { diente que un niño ha puesto para él. }\end{array}$ & \\
\hline & $\begin{array}{l}\text { Dado que el diente se movía, los } \\
\text { expertos decidieron extraerlo. }\end{array}$ & \\
\hline & $\begin{array}{l}\text { El niño estaba muy interesado en conocer } \\
\text { a Ratón Pérez, de hecho decidió } \\
\text { esperarlo despierto. }\end{array}$ & \\
\hline
\end{tabular}


En definitiva, deberíamos obtener una respuesta similar a la que figura a continuación:

\begin{tabular}{|c|c|c|}
\hline Orden & Texto reformulado & $\begin{array}{c}\text { Correspondencia con el texto } \\
\text { original }\end{array}$ \\
\hline 3 & $\begin{array}{l}\text { El rey Buby quiso afrontar el peligro sin } \\
\text { recurrir a ningún remedio, pese a que los } \\
\text { médicos quisieron ponerle cloroformo. }\end{array}$ & $\begin{array}{l}\text {... Pero el rey Buby era animoso y } \\
\text { valiente y empeñóse en arrostrar el } \\
\text { peligro cara a cara }\end{array}$ \\
\hline 9 & $\begin{array}{l}\text { En resumidas cuentas, que al final el rey } \\
\text { Buby vio a Ratón Pérez. }\end{array}$ & $\begin{array}{l}\text { vio delante de sí, de pie sobre la } \\
\text { almohada, un ratón muy pequeño }\end{array}$ \\
\hline 6 & $\begin{array}{l}\text { Como venía siendo costumbre, el niño } \\
\text { dejó el diente y una carta debajo de la } \\
\text { almohada. Ahora bien, lo que pretendía } \\
\text { hacer después, conocer al ratón, era del } \\
\text { todo inusitado. }\end{array}$ & $\begin{array}{l}\text { Puso con mucho primor debajo de } \\
\text { la almohada la carta con el diente } \\
\underline{\text { dentro }}\end{array}$ \\
\hline 4 & $\begin{array}{l}\text { La reina era una mujer inteligente, por } \\
\text { consiguiente no escuchaba a quienes } \\
\text { trataban de hacerle la pelota. }\end{array}$ & $\begin{array}{l}\text { Su Majestad la Reina. (...) esta } \\
\text { Señora, que como mujer lista no } \\
\text { fiaba de aduladores }\end{array}$ \\
\hline 8 & $\begin{array}{l}\text { El rey Buby intentaba no pestañear, así y } \\
\underline{\text { todo }} \text {, el sueño terminó por vencerlo. }\end{array}$ & $\begin{array}{l}\text { A poco abría Buby mucho los } \\
\text { ojitos, luchando contra el sueño } \\
\text { que se los cerraba: cerróselos al fin } \\
\text { del todo, }\end{array}$ \\
\hline 1 & $\begin{array}{l}\text { El diente se movía, de ahi que todos } \\
\text { dedujeran que el rey Buby iba a empezar } \\
\text { a perder sus dientes de leche. }\end{array}$ & $\begin{array}{l}\text { Todo indicaba que había llegado } \\
\text { para Su Majestad la hora de mudar } \\
\text { los dientes }\end{array}$ \\
\hline 10 & $\begin{array}{l}\text { Debido a que era un ratón muy educado, } \\
\text { no dijo directamente que se tenía que ir. } \\
\text { Así pues, se limitó a sugerir que tenía que } \\
\text { visitar otra calle para recoger el diente de } \\
\text { otro niño. }\end{array}$ & $\begin{array}{l}\text { Ratón Pérez insinuó hábilmente, } \\
\text { sin faltar a la etiqueta, que le era } \\
\text { preciso acudir aquella misma } \\
\text { noche a la calle de Jacometrezo } \\
\text { número 64 para recoger el diente } \\
\text { de otro niño }\end{array}$ \\
\hline 5 & $\begin{array}{l}\text { Ratón Pérez siempre ha cumplido con su } \\
\text { labor. Dicho de otro modo, no se conoce } \\
\text { ningún caso en el que haya dejado el } \\
\text { diente que un niño ha puesto para él. }\end{array}$ & $\begin{array}{l}\text { sin que haya memoria de que } \\
\text { nunca dejase Ratón Pérez de venir } \\
\text { a recoger el diente }\end{array}$ \\
\hline 2 & $\begin{array}{l}\text { Dado que el diente se movía, los } \\
\text { expertos decidieron extraerlo. }\end{array}$ & $\begin{array}{l}\text { decretóse al cabo sacar a } \mathrm{Su} \\
\text { Majestad el diente... }\end{array}$ \\
\hline 7 & $\begin{array}{l}\text { El niño estaba muy interesado en conocer } \\
\text { a Ratón Pérez, de hecho decidió } \\
\text { esperarlo despierto. }\end{array}$ & $\begin{array}{l}\text { sentóse encima dispuesto a esperar } \\
\text { a Ratón Pérez aunque fuese } \\
\text { necesario velar hasta el alba. }\end{array}$ \\
\hline
\end{tabular}

Corregimos sus respuestas en gran grupo y nos aseguramos de que los discentes comprenden los marcadores discursivos que aparecen en la tabla anterior en cursiva 
y subrayados. Una vez que sea así, les pedimos que los clasifiquen en la siguiente tabla ${ }^{7}$.

\begin{tabular}{|l|l|}
\hline \multicolumn{1}{|c|}{ USO } & MARCADOR \\
\hline Expresan la consecuencia & \\
\hline Expresan la causa & \\
\hline $\begin{array}{l}\text { Admiten una información opuesta pero } \\
\text { introducen un argumento contrario }\end{array}$ & \\
\hline $\begin{array}{l}\text { Matizan el primer miembro de la } \\
\text { argumentación, lo contra-argumentan }\end{array}$ & \\
\hline Explican introduciendo & \\
\hline Recapitulan argumento & \\
\hline $\begin{array}{l}\text { Refuerzan un anoya } \\
\text { información que lo apoya }\end{array}$ & \\
\hline
\end{tabular}

Llegados a este punto, decimos a los alumnos que individualmente actualicen el estilo del texto. Para ello deben marcar todas las formas gramaticales que son arcaicas y sustituirlas por su correspondiente forma actual, de esta manera les hacemos ver que la colocación de los pronombres actual no coincide con la antigua.

Seguidamente les ofrecemos una serie de palabras (columna de la izquierda) y les decimos que equivalen a algunas palabras que aparecen en el texto. Les pedimos que las identifiquen y que las escriban en la columna de la derecha ${ }^{8}$.

\begin{tabular}{|l|l|}
\hline Palabras propuestas: & Palabras del texto: \\
\hline Detrás de & \\
Finalmente & \\
Anestesiarle & \\
Enfrentar & \\
Roja & \\
Bandeja, canasto o fuente & \\
Lámparas & \\
Estar despierto & \\
\hline
\end{tabular}

${ }^{7}$ Expresan la consecuencia: de ahí que, así pues, por consiguiente. Expresan la causa: debido a, dado que. Admiten una información opuesta pero introducen un argumento contrario: pese a, ahora bien. Matizan el primer miembro de la argumentación, lo contraargumentan: así y todo. Explican: dicho de otro modo. Recapitulan: Dicho de otro modo. Refuerzan un argumento, introduciendo información que lo apoya: de hecho.

${ }^{8}$ Detrás de: en pos de, Finalmente: al cabo, Anestesiarle: cloroformizarle, Enfrentar: arrostrar, Roja: encarnada, Bandeja, canasto o fuente: azafate, Lámparas: arañas, Estar despierto: velar, Asombrosa: pasmosa. Se han mantenido los morfemas de las palabras, porque, aunque son una pista ineludible para realizar bien la actividad, el objetivo es trabajar con el vocabulario y por ello no tiene sentido complicar la actividad. 
Asombrosa

Evaluación: La evaluación de esta actividad se asienta sobre los siguientes criterios:

- El/la discente comprende el texto.

- El/la discente comprende el uso de los marcadores discursivos.

- El/la discente identifica giros arcaicos.

- El/la discente comprende el vocabulario por el que se le pregunta.

Actividad comunicativa de la lengua: Interacción. Expresión oral. Comprensión oral.

Descripción de la actividad: Después, tras organizar a los alumnos en grupos de unas cuatro personas, les pedimos que conversen para decidir cómo continúa el cuento. Luego cada grupo, de forma oral, nos cuenta su versión. Finalmente la profesora comunica a sus estudiantes que ratón Pérez accede a la petición del rey y continúa leyendo en voz alta a los alumnos los fragmentos restantes sin que los discentes los tengan. Transcurrida la lectura tratamos de evaluar qué grupo había acertado más en su versión. Posteriormente la profesora entrega una fotocopia con el resto de fragmentos que acaba de leer.

\section{RATÓN PÉREZ (fragmentos Continuación)}

Fuera de sí de contento, tiróse el rey Buby de la cama y comenzó a ponerse su blusita. Mas Ratón Pérez saltó de repente sobre su hombro, y le metió por la nariz la punta del rabo: estornudó estrepitosamente el reyecito, y por un prodigio maravilloso, que nadie hasta el día de hoy ha podido explicarse, quedó convertido, por el mismo esfuerzo del estornudo, en el ratón más lindo y primoroso que imaginaciones de hadas pudieran soñar.

(...) Faltaba ya tan sólo subir a la última buhardilla (...) que era donde Gilito vivía. Todo era entrada en aquella habitación abierta a todos los vientos (...) Encaramóse el rey Buby en el palo de una silla sin asiento, única que había y desde allí pudo abarcar todo aquel cuadro de horrible miseria (...) No había allí más muebles que la silla que servía de observatorio al rey Buby, un cesto de pan vacío, colgado del techo a la altura de la mano, y en el rincón menos expuesto a la intemperie, una caja de pajas y de trapos, en que dormían abrazados Gilito y su madre.

(...) ¿Cómo era posible que no hubiese sabido él hasta entonces que había niños pobres que tenían hambre y frío y se morían de miseria y de tristeza en un horrible camaranchón?... Ni mantas quería él ya tener en su cama, mientras hubiese en su reino un solo niño que no tuviera por lo menos tres calzones (...) Ratón Pérez (...) procuró calmar el dolor del rey Buby enseñándole la brillante monedita de oro que iba a poner bajo la almohada de Gilito, en cambio de su primer diente. 
(...) Emprendieron el viaje de vuelta silenciosos (...) y media hora después entraba el rey Buby en su alcoba con Ratón Pérez.

Tornó allí éste a meter en la nariz del rey la punta de su rabo; estornudó de nuevo Buby estrepitosamente, y encontróse acostadito en su cama, en los brazos de la Reina que le despertaba como todos los días con un cariñoso beso de madre.

Creyó, que todo había sido sueño, mas levantó prontamente la almohada, buscando la carta para Ratón Pérez que había puesto allí la noche antes, y la carta había desaparecido.

En su lugar había un precioso estuche (...) regalo magnífico que le hacía el generoso Ratón Pérez en cambio de su primer diente.

Una vez que los alumnos tengan el texto, han de utilizar individualmente algunos de los marcadores discursivos vistos anteriormente para reformular esta segunda parte del texto y hacer un resumen que entregan a la profesora.

Evaluación: Esta actividad se evalúa teniendo en cuenta los siguientes puntos:

- El/la discente cuenta una versión coherente con los fragmentos anteriores.

- El/la discente defiende sus puntos de vista en dentro del grupo con argumentos sólidos.

- E1/la discente se expresa con fluidez y propiedad.

- El /la discente respeta las convenciones y estructura del cuento.

- El /la discente emplea correctamente los marcadores discursivos.

Actividad comunicativa de la lengua: Expresión escrita.

Descripción de la actividad: La profesora, a modo de curiosidad, cuenta a los alumnos que según el cuento anterior, la vivienda de Ratón Pérez está en Madrid, en la Calle Arenal $n^{\circ} 8$ y que, si van a Madrid, encontrarán una placa en dicha ubicación dedicada a su memoria y un museo sobre Ratón Pérez.

A continuación, la profesora proyecta el tráiler de la película El ratón Pérez 2 disponible en http://www.youtube.com/watch? $\mathrm{v}=\mathrm{dQsXTEv} 9 \mathrm{sXU} \&$ feature=related y pide a los alumnos que hagan una lista de lo que, a juzgar por las imágenes, creen que le sucede a Ratón Pérez en esta película. Entre todos corregimos sus sugerencias, sin buscar tampoco hacer una lista exacta, sino, más bien, comprobar que han comprendido el tráiler y que argumentan sus respuestas con coherencia.

Después pedimos a los alumnos que piensen en el cuento que en su país se narra a los niños que se les ha caído un diente. Se les pide que imaginen cómo 
puede ser en la actualidad la vida del protagonista de ese cuento: obstáculos a los que se enfrenta, qué problemas tiene, cómo es su situación civil y laboral o su estado de ánimo, etc. y, a partir de ahí, los alumnos tienen que hacer una versión moderna (y divertida, a ser posible, ) del cuento tradicional.

Evaluación: Para la corrección de esta actividad tenemos en cuenta lo siguiente:

- El/la discente estructura la información correctamente.

- El/la discente escribe un texto coherente y con cohesión.

- El/la discente respeta las convenciones del cuento.

\subsubsection{Finalizamos con una canción sobre cuentos}

Actividad comunicativa de la lengua: Comprensión escrita. Comprensión oral. Expresión oral. Expresión escrita.

Descripción de la actividad: Para finalizar el trabajo con los cuentos, llevamos al aula una canción del grupo Celtas cortos, titulada: Cuéntame un cuento ${ }^{9}$. Avisamos a los discentes de que vamos a trabajar con una canción que trata sobre los cuentos.

A continuación les damos la letra de la canción, pero les informamos de que en ella se han colado las definiciones de algunas palabras. Su tarea es sustituir las definiciones por el término definido. Esto lo harán en primer lugar de forma individual y después cotejando sus respuestas con su compañero/a.

\section{CUÉNTAME UN CUENTO (Celtas cortos)}

Cuéntame un relato, generalmente indiscreto, de un suceso. Relación, de palabra o por escrito, de un suceso falso o de pura invención. Narración breve de ficción y verás que contento me voy a la cama y tengo lindos actos de dormir. Acto de representarse en la fantasía de alguien, mientras duerme, sucesos o imágenes. Estos mismos sucesos o imágenes que se representan. Gana de dormir.

(ESTRIBILLO)

Pues resulta que era un monarca o príncipe soberano de un reino. Pieza principal del juego de ajedrez, la cual camina en todas direcciones, pero solo de una casa a otra contigua, excepto en el enroque. Carta duodécima de cada palo de la baraja española que tenía tres hijas las metió en tres botijas y las tapó con pez y las pobres mujeres que por sí gozan o poseen un Estado que tiene el título de principado. Mujeres del príncipe lloraban desconsoladas y su padre les gritaba que por favor se callaran.

(ESTRIBILLO)

${ }^{9}$ Para esta actividad es preciso adaptar el texto original de la canción Cuéntame un cuento del grupo Celtas Cortos. 
Las princesas se escaparon por un hueco que existía que las llevó hasta la vía del medio de transporte que circula sobre raíles, compuesto por uno o más vagones arrastrados por una locomotora, que va para Italia y en Italia se perdieron y llegaron a Jamaica se pusieron hasta el culo de bailar reggae en la Ribera del mar o de un río grande, formada de arenales en superficie casi plana. Porción de mar contigua a esta ribera.

(ESTRIBILLO)

Bailando en la playa estaban cuando apareció su padre con la vara de avellano en la parte del cuerpo humano unida a la extremidad del antebrazo y que comprende desde la muñeca inclusive hasta la punta de los dedos, amenazando. Fue tras ellas como pudo y tropezó con la Vasija de cristal, vidrio, barro cocido u otro material, con el cuello estrecho, que sirve para contener líquidos, que tenía genio dentro, que tenía genio fuera. (ESTRIBILLO)

Les concedió dos y uno deseos y ahora felices estamos. Y colorín colorado este cuento se ha acabado.

Tras dejar un tiempo para realizar la actividad, ponemos la canción. Los estudiantes corrigen individualmente las respuestas. Después planteamos los siguientes interrogantes y ponemos la canción una vez más para que puedan responder:

- ¿A qué hora crees que se pide que se cuente un cuento?

- ¿Qué imaginas que está haciendo y dónde está la persona que pide que se le cuente un cuento según la letra de la canción?

Finalmente, pedimos a los alumnos que, en parejas y con el texto de la canción que han trabajado presente, conviertan el cuento que se cuenta en la canción en un cómic. Una vez terminados, colgamos los cómics por el aula para que todos los alumnos puedan verlos.

Evaluación: La evaluación de esta actividad tiene en cuenta los siguientes ítems:

- El/la discente comprende el texto de la canción y el texto de las definiciones.

- El/la discente identifica los términos aludidos en las definiciones.

- E1/la discente responde con coherencia a las preguntas planteadas tras la escucha de la canción.

- El/la discente escribe en el cómic un texto que refleja el cuento narrado en la canción.

\subsection{Actividades con el nivel B2}

\subsubsection{Trabajamos con Caperucita Roja}

Actividad comunicativa de la lengua: Expresión oral. Interacción.

Descripción de la actividad: El trabajo con este cuento se divide a su vez en tres partes. Para la primera de ellas necesitamos unas viñetas que nos transmitan el contenido del cuento de Caperucita roja. En concreto las siguientes ilustraciones 
han sido realizadas específicamente para este artículo por Andrew Drenth, profesor de español en el Leon M. Goldstein High School de Brooklyn (Nueva York).

Recortamos las siguientes viñetas. A cada pareja de alumnos le entregamos un juego completo de viñetas, dadas la vuelta y desordenadas ${ }^{10}$. Cuando ya hemos repartido todos los juegos de viñetas, los alumnos al mismo tiempo dan la vuelta a las imágenes. Pedimos a los alumnos que identifiquen el cuento.

Con el fin de que salga a la luz parte del léxico propio de éste y tomando como base las ilustraciones, hacemos preguntas como: ¿Sabéis cómo se llama lo que lleva la protagonista puesto? ¿Y lo que lleva en el brazo? Etc. Damos un tiempo para que ordenen las viñetas. A continuación corregimos el orden. La profesora pregunta al hilo de la corrección qué es lo que sucede en cada viñeta e incluso por algunos detalles del cuento que estén relacionados con los errores que aparecerán en la siguiente actividad ${ }^{11}$.

Evaluación: Como esta actividad nos sirve de preparación para la siguiente, no hay evaluación posible. Pretendemos simplemente que todos los alumnos conozcan el contenido del cuento para poder realizar la siguiente actividad.

\footnotetext{
${ }^{10}$ En las ilustraciones que a continuación se presentan aparece un número que indica el orden de las viñetas y se ha incluido ad hoc para la exposición de este artículo. Dicho número habría que suprimirlo si se pretende llevar al aula esta actividad, de lo contrario no tendría sentido pedir a los alumnos que ordenaran las viñetas.

${ }^{11}$ Es necesario realizar esta parte antes de la segunda, ya que, si por un casual hay algún alumno que tiene olvidado el cuento o lo desconoce, tiene opción de refrescarlo o de conocer en esencia el argumento y algunos detalles. Además damos a conocer parte del vocabulario que aparece en el cuento antes de contarlo.
} 


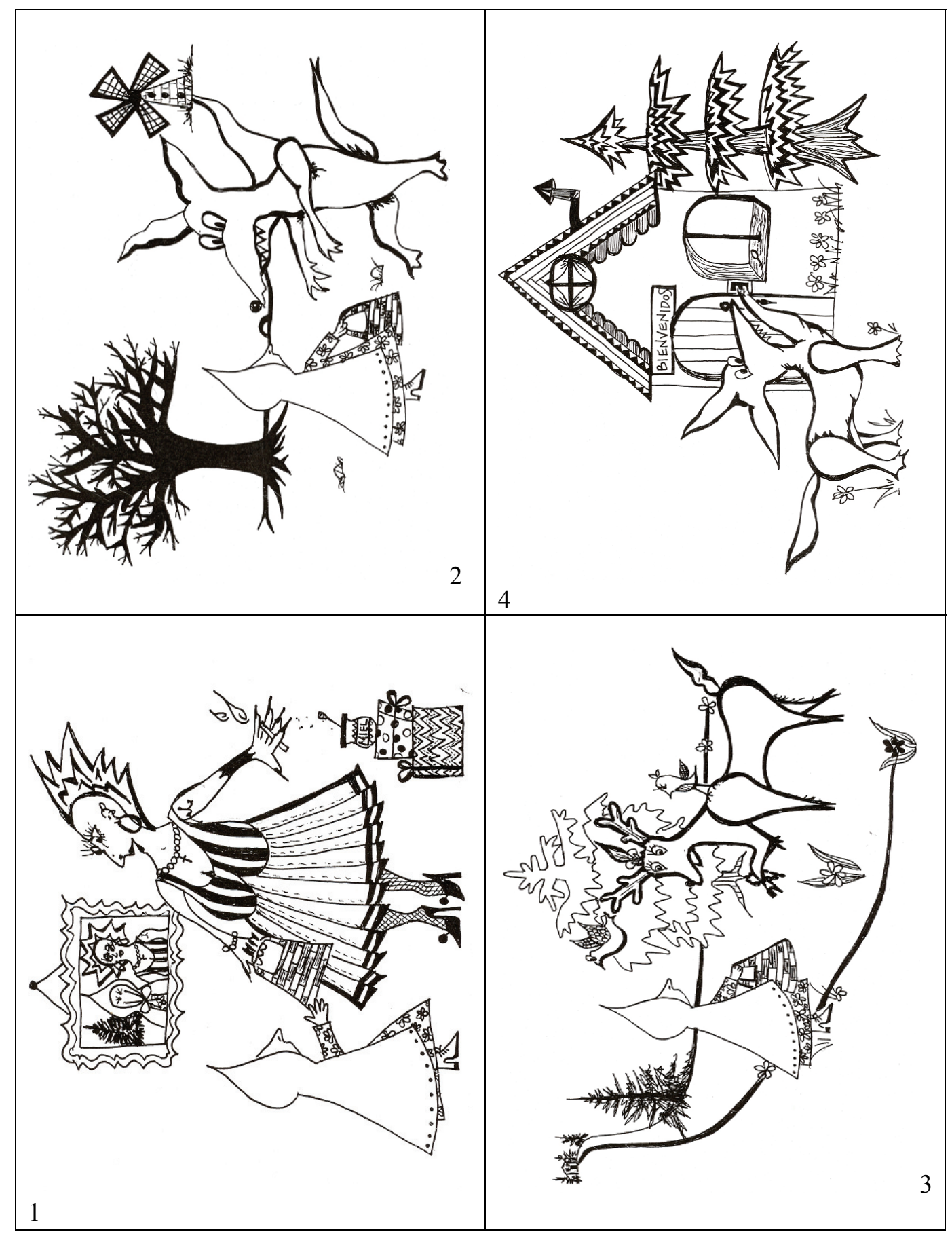




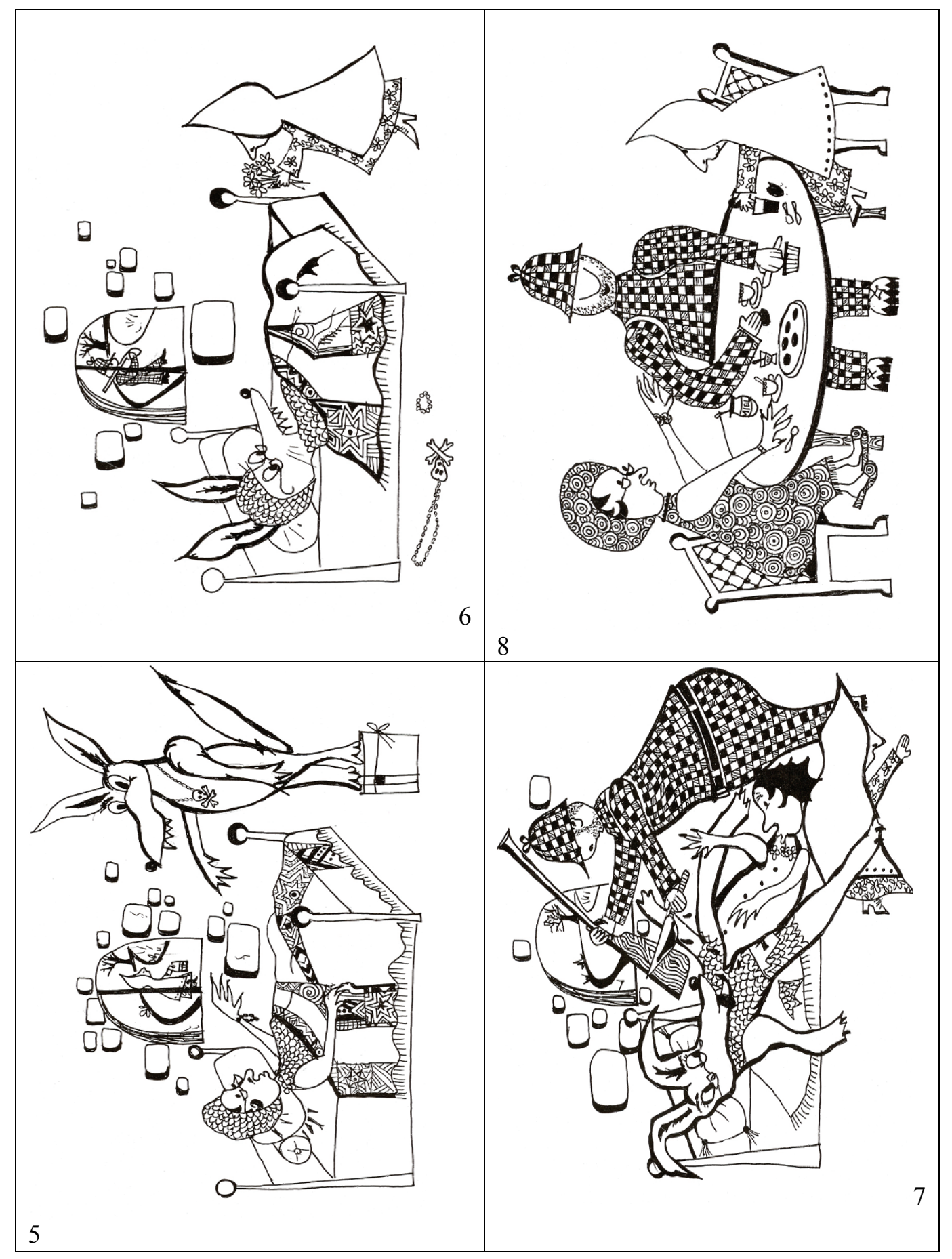


Una vez que nos hemos asegurado de que todos parten del mismo punto, esto es, que todos conocen en esencia el argumento y algunos detalles del cuento, comenzamos con la segunda parte.

Actividad comunicativa de la lengua: Comprensión oral.

Descripción de la actividad: La profesora anuncia a los alumnos que va a contarles el cuento en voz alta, sin embargo el texto no es exacto del todo, ya que la versión que tenemos, incluye algunos errores, veintidós en total, que han de detectar. Los alumnos tienen como guía el juego de viñetas ordenado encima de sus mesas, lo cual les va a resultar útil para no perderse en la narración y poder detectar errores. La profesora lee sin que los alumnos tengan el texto presente, ya que se trata de una actividad de comprensión oral. En el texto que leemos aparece subrayada la información errónea.

\section{CAPERUCITA ROJA ${ }^{12}$ ( versión con errores) $^{-1}$}

Érase una vez una niña muy bonita. Su madre le había hecho una capa roja y, como a la muchacha no le gustaba nada, la llevaba muy a menudo, tanto que todo el mundo en el pueblo la llamaba Caperucita Roja.

Un día su madre le pidió que llevase unas cervezas y unos bocadillos a su abuela que vivía con el cazador al otro lado del bosque y se encontraba enferma. Le recomendó que no se entretuviera por el camino y que hablase con extraños para conocer gente, pues cruzar el bosque era muy divertido ya que siempre andaba acechando por allí un lobo malvado.

Caperucita Roja recogió la cesta con los bocadillos y las cervezas y se puso en camino. La niña tenía que atravesar el bosque para llegar a casa de su abuela pero no le daba miedo porque allí siempre tenía muchos amigos: los pájaros, las ardillas, los ciervos... Iba caminando por el bosque, cuando de repente vio al lobo, que era enorme, delante de ella. El lobo sintió muchas ganas de invitarla a un café, pero no se atrevió porque andaban por el bosque algunos leñadores. Así que se conformó con preguntarle: -¿A dónde vas? La pobre niña le contestó: - Voy a casa de mi abuela a llevarle esta cesta que le envía mi madre. - ¿Vive muy lejos?, le preguntó el lobo. - Sí, contestó ella. ¿Ve aquel molino allí a lo lejos? Pues hay que seguir el sendero hasta allí y tras el molino está la casa de mi abuela.

El lobo le dijo a la niña que él conocía muy bien el bosque y por eso sabía que había un camino más corto, le dijo: tienes que ir por ahí, indicándole el camino más corto.

En cuanto Caperucita se echó a andar él se fue corriendo velozmente por el camino más

\footnotetext{
${ }^{12}$ Texto adaptado de Perrault, Charles (2000): Cuentos completos de Charles Perrault, Madrid, Anaya.
} 
largo para llegar más tarde a casa de la abuela. Mientras tanto, Caperucita, como pensaba que iba a tener tiempo de sobra ya que el lobo le había indicado el camino más corto, decidió coger flores, pensando que su abuela se pondría muy contenta al ver el ramo que le había preparado.

No tardó mucho en lobo en llegar a casa de la abuela. Llamó TOC TOC -¿Quién es? Soy la chica de la tele-tienda, Caperucita, dijo el lobo intentando aclarar la voz, te traigo un aspirador en oferta que te envía mi madre. La buena de la abuela que estaba en la asomada al balcón porque se encontraba un poco mal, le gritó: - Espera que te lanzo mi larga cabellera para que subas. El lobo entró, se lanzó sobre la abuela y la devoró en un santiamén, ya que hacía más de tres días que no comía.

Después cerró la puerta y vistiéndose con zapatos de tacón de aguja y un chándal de deporte de la abuela, se metió en la cama y esperó a que Caperucita llegara. Al poco Caperucita llamó a la puerta TOC TOC - ¿Quién es? Caperucita roja, al oír el vozarrón del lobo tuvo miedo al principio, pero creyendo que su abuela estaba acatarrada contestó: -Soy tu nieta, Caperucita, te traigo una cesta de navidad. El lobo, intentando suavizar la voz le dijo- "la llave está en el alféizar de la ventana" Caperucita la cogió y abrió. Al verla entrar el lobo le dijo: - ¿no es verdad, ángel de amor, que en esta apartada orilla, más dulce la luna brilla y se respira mejor? La niña se acercó y vio que su abuela estaba muy cambiada. - Abuelita, abuelita, ¡qué ojos tan grandes tienes! - Son para verte mejor. Respondió el lobo tratando de imitar la voz de la abuela. - Abuelita, abuelita, ¡qué brazos más largos tienes! - Es que hago pesas, hija mía. - Abuelita, abuelita, ¡qué orejas más grandes tienes! - Son para oírte mejor, niña mía. - Abuelita, abuelita, iqué dientes tan grandes tienes! - Son para comerte mejor. Y diciendo esto la niña gritó y el lobo malvado se abalanzó sobre ella y le dio un beso. Lo mismo que había hecho con la abuela.

Mientras tanto, un cazador que estaba cerca y que había escuchado los gritos, preocupado decidió ir para comprobar si todo estaba en orden en la casa de la abuela. Cuando llegó vio que la puerta estaba abierta, entró y se encontró con el lobo que estaba tumbado en la cama de resaca. El cazador sacó su cuchillo y rajó el vientre del lobo para hacer chorizos, la abuelita y Caperucita salieron vivas de allí. Para castigar al lobo malo por su conducta, el cazador llenó el vientre del lobo con los bocadillos y las cervezas y lo volvió a cerrar. Una vez que el lobo hubo despertado del largo sueño, se sintió sediento y se fue a beber al estanque más próximo. Como las piedras pesaban mucho, el lobo cayó en el estanque de cabeza y se ahogó. En cuanto a Caperucita y su abuela no sufrieron más que un gran susto, aunque Caperucita aprendió la lección, prometió a su abuela no habar con desconocidos. De ahora en adelante seguiría las recomendaciones de su madre.

Y colorín colorado este cuento se ha acabado.

La profesora lee el texto un par de veces. Durante la primera lectura, el cometido de los alumnos es detectar la información errónea y tomar nota de cuantos gazapos o mentiras identifiquen en la narración, es suficiente con que 
capten la idea, no se trata de hacer una copia literal a modo de dictado. Durante la segunda lectura les pedimos que, por el contexto y por sus conocimientos sobre el texto, deduzcan la información original de aquellos casos en los que sea posible. Para facilitarnos el trabajo y hacernos comprender mejor entregamos a los alumnos un esquema como el que sigue, pero con 22 puntos dentro de cada columna.

\begin{tabular}{|ll|l|}
\hline $\begin{array}{l}\text { Primera lectura: } \\
\text { incorrecta }\end{array}$ & Información & $\begin{array}{l}\text { Segunda lectura: posible información } \\
\text { original }\end{array}$ \\
\hline 1 & & 1 \\
2 & 2 \\
3 & 3 \\
$4 \ldots$ & $4 \ldots$ \\
\hline
\end{tabular}

Para que sea factible realizar esta actividad, la profesora lee pausadamente todo el texto, de esta forma damos tiempo a los alumnos para que escriban, de lo contrario la actividad podría favorecer sólo a aquellos alumnos que fuesen rápidos escribiendo y no a los que comprendieran el texto ${ }^{13}$. Finalmente, mediante una puesta en común de las notas que han tomado, corregimos sus respuestas, teniendo en cuenta que en la segunda parte no es posible responder con la información exacta en todos los casos, por lo que la profesora se muestra flexible ante las respuestas de los estudiantes, siempre y cuando éstas sean coherentes con el resto del texto.

Evaluación: Al evaluar esta actividad tenemos en cuenta que:

- El/la discente haya identificado los errores.

- El/la discente sugiera información original coherente con el texto que se cuenta, lo que demuestra que comprende el texto oral.

Por último, para la tercera parte, les invitamos a que comprueben que en los cuentos, igual que en la vida real, todo depende de quién cuente la historia, ya que no todos los personajes tienen la misma versión de los hechos.

Actividad comunicativa de la lengua: Comprensión escrita. Expresión escrita. Comprensión oral.

Descripción de la actividad: Repartimos el siguiente texto, que no es sino la versión del lobo sobre los mismos hechos narrados anteriormente.

${ }^{13} \mathrm{Al}$ escribir damos opciones de participación a todos. Si lo hiciéramos a mano alzada, probablemente algún alumno más rápido que los demás podría acaparar la actividad. Aunque si no disponemos de mucho tiempo también se puede hacer oralmente. 


\section{EL CUENTO DE “CAPERUCITA ROJA" CONTADO POR EL LOBO ${ }^{14}$}

El bosque era mi casa. Allí vivía yo y lo cuidaba. Procuraba tenerlo siempre limpio y arreglado. Un día de sol, mientras estaba recogiendo la basura que habían dejado unos domingueros, oí unos pasos. De un salto me escondí detrás de un árbol y vi a una chiquilla, más bien pequeña, que bajaba por el sendero, llevando una cestita en la mano.

Enseguida sospeché de ella porque vestía de una forma un tanto estrafalaria, toda de rojo, con la cabeza cubierta, como si no quisiera ser reconocida. Naturalmente me paré para ver quién era. Le pregunté cómo se llamaba, a dónde iba, y otras cosas por el estilo. Me contó que iba a llevar la comida a su abuelita. Me pareció una persona honesta y buena, pero lo cierto es que estaba en el bosque y resultaba sospechosa con aquella extraña caperuza. Así que le advertí, sencillamente, de lo peligroso que era atravesar el bosque sin antes haber pedido permiso y con ese atuendo tan raro. Después la dejé que se fuera por su camino, pero yo me apresuré a ir a ver a su abuelita.

Cuando vi a aquella simpática viejecita le expliqué el problema y ella estuvo de acuerdo en que su nieta necesitaba una lección. Quedamos en que se quedaría fuera de la casa, pero la verdad es que se escondió debajo de la cama; yo me vestí con su ropa y me metí dentro de la cama. Cuando llegó la niña la invité a entrar en el dormitorio. Enseguida dijo algo poco agradable sobre mis orejas. Anteriormente también me había dicho alguna cosa desagradable, pero hice lo que pude para justificar que mis grandes orejas me permitían oírla mejor. Quise decirle también que me encantaba escucharla y que quería prestar mucha atención a lo que me decía, pero ella hizo enseguida otro comentario sobre mis ojos saltones. Podéis imaginar que empecé a sentir cierta antipatía por esta niña que aparentemente era muy buena, pero bien poco simpática. Sin embargo, como ya es costumbre en mí poner la otra mejilla, le dije que mis ojos grandes me servirían para verla mejor.

El insulto siguiente sí que de veras me hirió. Es cierto que tengo grandes problemas con mis dientes que son enormes, pero aquella niña hizo un comentario muy duro. Refiriéndose a ellos y, aunque sé que tendría que haberme controlado mejor, salté de mi cama y le dije que mis dientes me servían para comérmela mejor.

Ahora, seamos sinceros, todo el mundo sabe que ningún lobo se comería a una niña. Pero aquella loca chiquilla empezó a correr por toda la casa gritando y yo detrás, intentando calmarla, hasta que se abrió de improviso la puerta y apareció un guardabosques con un hacha en la mano. Lo peor es que yo me había quitado ya el vestido de la abuela y enseguida vi que estaba metido en un lío, así que me lancé por una ventana que había abierta y corrí lo más veloz que pude.

Me gustaría decir que así fue el final de todo aquel asunto, pero aquella abuelita nunca

${ }^{14}$ Texto extraído de http://sapiens.ya.com/vidalogia/index4.htm 
contó la verdadera historia. Poco después empezó a circular la idea de que yo era un tipo malo y antipático y todos empezaron a evitarme. No sé nada más de aquella niña con aquella extravagante caperuza roja, pero, después de aquel percance ya nunca he vuelto a vivir en paz.

Tras acabar la lectura del cuento preguntamos a los alumnos por la siguiente información:

¿Cómo te imaginas al lobo tras leer su versión?

¿A quién asociarías la idea de poner la otra mejilla?

¿Qué aspectos del cuento tradicional han servido al lobo para justificar su actitud y argumentar su punto de vista?

¿Cómo te imaginas a Caperucita tras la lectura de la versión del lobo?

¿En qué posición deja el lobo a la abuelita de Caperucita?

Después, la profesora propone una lluvia de ideas sobre cuentos tradicionales famosos, con el objetivo de explicitar algunos de los títulos en español. Los alumnos, como era de esperar, se ven obligados a dar pistas sobre los argumentos, ya que desconocen los títulos exactos en español. La profesora anota los títulos propuestos en la pizarra y sugiere alguno que no se haya mencionado.

Con los títulos de los cuentos anotados en la pizarra y basándose en la versión del lobo, en grupos de tres, los alumnos tratan de hacer un escrito similar desde la perspectiva del antagonista de otro cuento. Cada grupo podrá elegir el cuento tradicional que quiera.

Una vez que cada grupo se ha decantado por un cuento, tiene que discutir qué elementos podrían resultar tan ambiguos en la versión original, que pudieran utilizarse para justificar al antagonista. Luego se les pide que escriban individualmente desde la perspectiva del antagonista una justificación a su actitud, inventando cuanta información sea necesaria. Dicho texto ha de incluir: valoraciones del antagonista, sus opiniones, sus contra-argumentaciones y la expresión de desacuerdos que pueda tener o de desaprobaciones. Para que la tarea les resulte más sencilla, entregamos a los estudiantes una hoja con la siguiente tabla $^{15}$ :

\begin{tabular}{|l|l|}
\hline FUNCIONES & EXPONENTES LINGÜÍSTICOS \\
\hline Valorar & 1. Es una buena/mala idea que + subjuntivo. \\
& 2. Qué bien/mal lo de... \\
& 3. Qué bien/mal que... \\
& 4. Encuentro/considero/ me parece/ Me resulta + \\
\hline
\end{tabular}

${ }^{15}$ En nuestro caso, estas funciones se habían visto con anterioridad en el curso de lengua que se estaba impartiendo, por lo que la escritura del cuento se planteaba en cierto modo como un repaso. Por otro lado, debido al tiempo del que disponíamos fue preciso acabar esta actividad en casa y continuar con ella al día siguiente. 


\begin{tabular}{|c|c|}
\hline & adjetivo/SN + que + subjuntivo. \\
\hline $\begin{array}{ll}\text { Dar } & \text { una } \\
\text { opinión } & \end{array}$ & $\begin{array}{l}\text { 1. A mi modo de ver... } \\
\text { 2. Según... } \\
\text { 3. Considero que... } \\
\text { 4. Yo diría que... } \\
\end{array}$ \\
\hline $\begin{array}{l}\text { Presentar un } \\
\text { contra- } \\
\text { argumento }\end{array}$ & $\begin{array}{l}\text { 1. Bueno/ya pero... } \\
\text { 2. Puede que me equivoque, pero creo que... } \\
\text { 3. No dudo (de) que..., no obstante... } \\
\text { 4. Sí, pero tampoco se puede olvidar que... }\end{array}$ \\
\hline $\begin{array}{l}\text { Expresar un } \\
\text { desacuerdo } \\
\text { rotundo }\end{array}$ & $\begin{array}{l}\text { 1. No estoy en absoluto de acuerdo. } \\
\text { 2. Estás muy equivocado. } \\
\text { 3. ¿Pero cómo puedes decir eso? } \\
\text { 4. No, no, eso no es cierto/ así/ verdad. }\end{array}$ \\
\hline $\begin{array}{l}\text { Expresar } \\
\text { desaprobación }\end{array}$ & $\begin{array}{l}\text { 1. Me parece fatal/horrible que + subjuntivo. } \\
\text { 2. iQué mal que...! } \\
\text { 3. No deberías/tendrías que + infinitivo compuesto. }\end{array}$ \\
\hline
\end{tabular}

Después, los miembros de cada grupo se intercambian dentro del grupo los textos escritos por ellos mismos con el objetivo de corregirlos en función de las pautas que les damos:

\section{Guía para revisar el borrador de tu compañero}

- Señala con $¿$ ? lo que no entiendas

- Subraya en rojo lo que te parezca más original

- Pon i! en lo que te parezca más sorprendente

- Di si algún párrafo necesita más información o más descripciones

- Corrige lo que consideres que está mal escrito gramatical y ortográficamente

- Comprueba que se siguen todos los pasos de los cuentos tradicionales

- Comprueba si los tiempos del pasado están utilizados correctamente

Tras las correcciones pertinentes y valoraciones internas, cada grupo selecciona el texto de mayor calidad por su estilo, gracia, corrección gramatical, originalidad... ${ }^{16}$ Una vez corregidos los textos y aclaradas dudas, cada grupo lee en voz alta, sin desvelar el título, la versión definitiva de su cuento al resto de los compañeros, quienes intentarán adivinar de qué cuento se trata. Finalmente la

${ }^{16}$ El texto elegido puede ser modificado nuevamente si el grupo así lo estima oportuno. 
profesora recoge todos los textos para corregirlos. Una vez corregidos y, si es preciso, pasados a limpio, se cuelgan por las paredes del aula para que puedan ser leídos por los alumnos.

Evaluación: Para evaluar esta actividad nos guiamos por los siguientes ítems:

- El/la discente estructura correctamente la información.

- El/la discente se expresa utilizando las expresiones vistas en clase.

- El/la discente presenta un texto creativo y con cierta ironía.

\section{CONCLUSIÓN}

Hemos presentado en este artículo algunas de las posibilidades que ofrecen los cuentos como recurso didáctico dentro del aula de Español Segunda Lengua (EL2). A través de los cuentos podemos trabajar diferentes aspectos de la lengua y plantear actividades de corte más gramatical o actividades más comunicativas, pero siempre con un contexto que nos sirva de referencia: el proporcionado por el propio cuento.

La evaluación hecha al hilo de las actividades, nos ha permitido valorar si los discentes comprendían lo que se les planteaba y si su nivel de respuesta era adecuado. Así mismo nos ha permitido valorar si la profesora debía reformular o hacer más hincapié en algunos contenidos.

Como curiosidad también diremos que los discentes manifestaron explícitamente su motivación ante este recurso.

\section{REFERENCIAS BIBLIOGRÁFICAS:}

ALBALADEJO GARCÍA, María Dolores (2007): "Cómo llevar la literatura al aula de ELE: de la teoría ala práctica", en MarcoELE. Revista de Didáctica ELE, 5, $1-51$

BARRERAS GÓMEZ, Asunción (2007): "Los cuentos orales en la enseñanza de español como lengua extranjera", en Las destrezas orales en la enseñanza del español L2/LE. XII Congreso internacional de ASELE, Servicio de Publicaciones de la Universidad de la Rioja vol. 1, 313-322.

COLLIE, Joanne y SLATER, Stephen (1991): Literature in the Language Classroom. A resource book of ideas and activities, UK, Cambridge handbooks for language teachers.

COLOMA, Luis (2002): Ratón Pérez, Madrid, Asociación Española de Amigos del libro infantil y juvenil.

CRESPO SASTRE, Ma . Teresa y GONZÁLEZ VILlÁN, Carlos (2007): "El cuento en la enseñanza del español como lengua extranjera: una propuesta didáctica", en Didáctica de la enseñanza para extranjeros: Actas del I Congreso internacional de Lengua, Literatura y Cultura española, 169-183. 
DELMIRO COTO, B. (2002): La escritura creativa en las aulas. En torno a los talleres literarios, Barcelona, Graó.

JOUINI, KHEMAIS (2008): "El texto literario en la clase de E/LE: Propuestas y modelos de uso", en Didáctica (Lengua y Literatura), Publicaciones Universidad Complutense, 20, 149-176.

SCHUMANN, John: "La adquisición de segundas lenguas: la hipótesis de la pidginización", en LICERAS, Juana (Comp.) (1992): La adquisición de las lenguas extranjeras. Hacia un modelo de análisis de la interlengua, Madrid, Visor.

MATA, Francisco Salvador (2000): Cómo prevenir las dificultades en la expresión escrita, Archidona (Málaga), Aljibe.

MOLINA, César Antonio (Dir.) (2006): Plan Curricular del Instituto Cervantes. Niveles de referencia para el español B1, B2, Madrid, Biblioteca Nueva.

NARANJO, María (1999): La poesía como instrumento didáctico en el aula de español como lengua extranjera, Madrid, Edinumen.

PERRAULT, Charles (2000): Cuentos completos de Charles Perrault, Madrid, Anaya.

SOLÉ, Isabel (2005): Estrategias de lectura, Barcelona, Graó.

UR, Penny (1997): A course in language teaching, Cambridge, Cambridge University Press.

VV. AA. (1987): Orientaciones didácticas sobre la lengua. Etapa 12 - 16 años, Madrid, Narcea S.A. de Ediciones.

http://es.wikipedia.org/wiki/Saturnino_Calleja [Última Consulta: 15 febrero 2011]. http://burgospedia1.wordpress.com/2010/10/26/saturnino-calleja-editor-fundadorde-la-editorial-calleja/ [Última Consulta: 15 febrero 2011].

http://cvc.cervantes.es/actcult/raton/default.htm [Última Consulta: 15 febrero 2011].

http://www.youtube.com/watch?v=dQsXTEv9sXU\&feature=related [Última Consulta: 15 febrero 2011].

http://sapiens.ya.com/vidalogia/index4.htm [Última Consulta: 15 febrero 2011]. 